\title{
Chapter 28 \\ Into a New Epoch: Capitalist Nature in the Plantationocene
}

\author{
Noboru Ishikawa
}

\begin{abstract}
This chapter delineates the characteristics of impacts and changes brought by the expansion of oil palm plantations to the biomass-rich interior region of Sarawak, Malaysia. It argues that many of the changes, both social and ecological, and the combination of the two, are derived from interfaces being formed when different and often distant landscapes, peoples, institutions and networks come into contact and are abruptly juxtaposed. Such new encounters have led to the temporal compression of succession - the transplanting, mobilisation, proliferation, reduction and extirpation of fauna, flora and human communities in a relatively short time. What emerges is a mixed landscape consisting of first nature and capitalist nature, where habitat fragmentation, biodiversity loss and multifaceted displacements proceed. Spatial compression brought by infrastructure development also connects the local community, both human and non-human, with distant people and markets, leading to a new kind of rural-urban continuum as well as the commodification of nature and labour. Along newly created commodity chains, there emerge numerous cultural encounters of individuals and social groups, adding a new social amalgam to the local community.
\end{abstract}

Keywords Sarawak Anthropocene $\cdot$ Capitalocene $\cdot$ Plantationocene $\cdot$ Plantation frontier - Oikoumene

\subsection{The Anthropocene and the Capitalocene}

We have now entered the Anthropocene, a new geo-historical period in which humans are the most powerful agent of change, according to some scholars. If they are correct, we are no longer in the Holocene geological epoch. In light of this, urgent actions

The original version of this chapter was revised: This chapter was previously published as non-open access. It has now been changed to open access under a CC BY NC ND 4.0 license. The correction to this chapter is available at https://doi.org/10.1007/978-981-13-7513-2_29

N. Ishikawa $(\bowtie)$

Center for Southeast Asian Studies, Kyoto University, Kyoto, Japan

e-mail: ishikawa@cseas.kyoto-u.ac.jp

(C) The Author(s) 2020, corrected publication 2021

N. Ishikawa, R. Soda (eds.), Anthropogenic Tropical Forests, Advances in Asian

Human-Environmental Research, https://doi.org/10.1007/978-981-13-7513-2_28 
are needed to respond to climate change and other human-induced environmental changes, if humans are the primary agents for change for the future trajectory of the Earth. Theories abound about just when this human influence became paramount, but many see the use of fossil fuels to support the Industrial Revolution as a crucial inflection point. The impact of humans is thus about the exploitation of buried organisms containing energy from photosynthesis and a result of millions of years of the natural anaerobic decomposition of buried organisms. In other words, biomass altered by heat and pressure over geological time lies at the heart of the Anthropocene's development, prosperity, and now crisis (Lewis and Maslin 2018).

Yet there are a variety of approaches in our search for a new epoch. 'Capitalocene' is one such example. The term pays more attention to the system of capitalism, governance as well as the mobilisation of labour and utilisation of natural resources that have led to global transformations. The notion of the Capitalocene has the advantage of attending to society, culture, history and power without restricting human influence only to the realm of scientific and technological inventions such as fire, steam engines and atomic bombs (Haraway 2015; cf. Moor 2017; Bonneuil and Fressoz 2017). On the one hand, natural scientists search for hints of change in natural phenomena such as 'golden spikes' left in a geological stratum, and look into conditions of climate, atmospheric chemistry, and the density and distribution of plant and animal species (Lewis and Maslin 2015: 174). On the other hand, social scientists examine changes in social formations, structure and governance as well as connections, networks, flows and the movement of things, labour and people under capitalism. In other words, while natural science Anthropocenologists employ large data sets on a global scale in search of an inflection point in the geological record and atmospheric change, social science Anthropocenologists present a civilisational critique that combines histories of the Earth system and world systems.

\subsection{Into the Plantationocene}

In lieu of a conclusion, I wish to introduce yet another historical periodisation, the 'Plantationocene', as a subcategory of the Anthropocene. In doing so, our research in this volume is located in the current debate. While the Anthropocene is defined in connection with the fossil fuel era, the Plantationocene is an epoch characterised by the emergence of a large-scale, monocropping production system across the surface of the Earth. ${ }^{1}$ Each constituent of this production system-plant, land, labour, technology and infrastructure-is mutually dependent and thus presumed to be essential to the operation of the whole (cf. Mintz 1959: 44). The emergent system is 'the model and motor for the carbon-greedy machine-based factory system that is often cited as an inflection point for the Anthropocene'(Haraway 2015: 162; cf.

\footnotetext{
${ }^{1}$ The term Plantationocene was generated and extensively discussed in a dialogue on the Anthropocene in a recorded conversation for Ethnos at the University of Aarhus, Denmark, in October 2014. The discussion was transcribed and published as 'Anthropologists are talking about the Anthropocene' in Ethnos (see Haraway et al. 2016).
} 
Haraway et al. 2016). In the course of human history, the monoculture plantation has transformed 'diverse kinds of human-tended farms, pastures, and forests into extractive and enclosed plantations' (Haraway 2015: 162). With the advent of the Plantationocene, multispecies forests and the remaining refugia are being wiped out (Tsing 2015b).

In the course of our research from 2010 to 2014, we have come to realise the salience of the Plantationocene's features, and we capture its latest and emerging moments in maritime Southeast Asia. Compared to the Malay Peninsula, which has experienced a century of oil palm cultivation and more than 30 years of downstream industrial sector development, what we witness in the riverine society of Sarawak is the formative stage of plantation expansion to upstream regions. Among many resource frontiers in Southeast Asia, Sarawak occupies a peculiar historical niche. Logging activity and the expansion of oil palm, both by the plantation system and on a smallholding basis, have proceeded concurrently. More importantly, people's livelihoods in Sarawak are still highly dependent on biomass-rich environs. In the course of our project, we had an opportunity to examine the very early stages of transformation from a biomass to land regime as well as subsistence and trade to market-orientated production. In other words, the crucial moment of the coming of the Plantationocene was unfolding in front our eyes during the study. ${ }^{2}$

Since 1492 the plantation mode of production has expanded to high biomass societies in the tropics. ${ }^{3}$ The arrival of Europeans in the Caribbean in that year, and the subsequent colonisation of the Americas, initiated a global process known as the Columbian Exchange in which the transoceanic movements of plants, populations and capital fundamentally changed the way agricultural commodities were produced. These cross-continental movements have resulted in the 'radical reorganization of a web of life on and beneath the soil without geological precedent' (Lewis and Maslin 2015: 174). The main characteristics of the Plantationocene reflect this reorganisation. The impacts of the meeting of Old World and New World human populations and plants led to the reorganisation and homogenisation of the Earth's biota and served to mark the beginning of a new geological epoch. In terms of stratigraphy, the plant species deracinated and cultivated as plantation crops in the sediments of the tropics may provide a common marker of the Plantationocene across many deposits because pollen is often well preserved in marine, lake sediments and peatland (Lewis and Maslin 2015: 175).

\footnotetext{
${ }^{2}$ By 1800 , when Alexander von Humboldt reached colonial plantations in Venezuela, the Plantationocene was already well under way. He witnessed the transformation of nature and described it as an interconnected living web. For him nature was a 'living whole' where organisms were bound together in a net-like intricate fabric (Wulf 2015).

${ }^{3}$ What distinguishes our research among pioneering studies on plantations (cf. Steward et al. 1956; Wolf 1982; Mintz 1985) is our multidisciplinary and multispecies approach. Through empirical research on site, we are able to add our findings to those of previous studies. For instance, for Steward's pioneering attempt to understand the Puerto Rican plantation society with a focus on local communities, sub-communities, and the level of social integration (Steward et al. 1956), we examine the social dynamics beyond plantation society, and to Wolf's attention to 'people without history', we add greater focus on more than human perspectives as well as histories of non-humans (cf. Tsing 2016).
} 


\subsection{Juxtaposition and New Interfaces}

Here I wish to delineate some of the socio-ecological characteristics of the Plantationocene through our study of one small area of the central Sarawak frontier. Many of the changes, social and ecological, and the combination of the two, are derived from interfaces formed when different and often distant landscapes, people and things come into contact. Such new encounters or spatial juxtapositions have led to the temporal compression of succession - the transplanting and mobilisation, proliferation, reduction and extirpation of plants, flora and people in a relatively short period of time. We have found that this compression of both space and time is an important feature of the plantation frontier. The landscapes are juxtaposed by force, for instance when remnant communal forests of pulau and plantations meet. This leads to the coexistence of nature and non-nature or the encounter of 'first nature' with 'capitalist nature' (Tsing 2015a). The juxtaposed landscape consisting of first nature and second nature brings about both ecological and social changes. As we have seen in the plantation frontier of central Sarawak, the juxtaposition of peat swamp forests, secondary forests, culturally preserved communal forests, swidden fields, reduced-impact logging sites, logged-over forests, acacia planted forests and oil palm plantations leads to habitat fragmentation where a habitat is being increasingly divided into more isolated pieces (Haddad et al. 2015). This fragmentation process increases forest edges where wind damage and changes in temperature and humidity may make the environment along the edges unsuitable for certain species, resulting in the available habitat becoming even smaller (Turner 1996; Laurance et al. 2016). ${ }^{4}$

Yet there may be a chance for the coexistence of first nature and capitalist nature on the plantation frontier. Our study has shown that reduced-impact logging practices are one effective way to prevent biodiversity loss. ${ }^{5}$ In addition, the initiative and conscious effort on the part of local peasants would contribute to the maintenance of a well-balanced, high-quality mixed landscape consisting of remnant forest, swidden fields, secondary forest and oil palm cultivation fields.

Spatial compression not only brings changes to ecological communities but also to humans. In the maritime frontier of Sarawak, profound changes have occurred both at the levels of the macro landscape and the micro household. Through the construction of road networks that link upriver and downriver supply chains, distant people are reconnected in a new manner distinctively different from relationships of the past. The landscape changes when people migrate to the roadside from the

\footnotetext{
${ }^{4}$ Due to fragmentation, more than $70 \%$ of the world's forests are now within $1 \mathrm{~km}$ of a forest edge, impacting on rainforest ecosystems across the globe (Haddad et al. 2015).

${ }^{5}$ An effective forest sustainability mechanism - ecosystem service certification - has been initiated by the Forest Stewardship Council, where management entities who wish to be certified for the maintenance of ecosystem services (carbon, biodiversity, watershed, soil and recreational services) must verify that their activities have no net negative impacts on selected ecosystem service(s). For a robust and cost-effective measurement method to evaluate a bundle of ecosystem services, see Kanehiro Kitayama (2013).
} 
riverside in order to plant their own oil palm. The social ties previously maintained along maritime riverine lines are now giving way to terrestrial ones. At the household level, families are spatially extended and consist of urban wage earners as well as those who stay close to cultivated oil palm forests inland. Labour as well as remittances from urban family members often support senior members of the community who engage in oil palm smallholding in rural areas. Spatial compression leads to a new kind of rural-urban continuum, while peri-urban space is functionally diminishing.

The transformation from a biomass to land regime, as well as from subsistence to market-orientated production, has resulted in an increase in the value of local land. In such a situation, although we foresee the coexistence of oil palm smallholders and plantations in close proximity, more intense competition is expected between the two. If the history of rubber expansion to maritime Southeast Asia in the interwar period is indicative, it may not take long for smallholders to upscale their production capacity to collectively match some of the large-scale plantations. What we currently see is the trend towards an enlarged oil palm peasantry in Sarawak. As a result, the competition for both land and labour is becoming acute between the plantation sector and smallholders. Under these circumstances, two modes of labour mobilisation for oil palm cultivation are likely to become more intense: the labour of local peasants at the fringe of corporate plantations is mobilised by the corporate sector, while local smallholders also mobilise extra-household labour to expand their farmland operations.

Along commodity chains that link production sites and consumption sites, there exist numerous cultural encounters of distant people. Take an encounter between the corporate sector and local communities as an example. Local people meet and interact with Bugis and Timorese plantation workers as well as Fuzhou Chinese in timber camps and Japanese businessmen procuring timber to be used as concrete-forming plywood in Tokyo. Such is a typical social field on the resource frontier under study. During our research, we often witnessed heated cockfights enjoyed both by local Ibans and Bugis migrants from Sulawesi. This kind of quotidian cultural encounter along commodity chains may add a new social amalgam to the multiethnic KemenaTatau basin.

The ecological, social and cultural compression that takes place along extended commodity chains is a characteristic of the Plantationocene. Since Sidney Mintz first discussed the Caribbean region as 'Oikoumene', the plantation frontier throughout the world has been repopulated by people, fauna and flora from elsewhere. They mixed together and formed a distinctive niche in world history. Such Plantationocene space, however, was 'only laggardly assimilated into social science' (Mintz 1996: 289). Belatedly, we add a new page to the examination from the perspective of multidisciplinary research that combines social and natural sciences. The findings are nevertheless place-specific. Despite such limitations, we hope some relevance is to be found for further empirical examinations in this frontier or elsewhere in other tropical biomass societies. Our research may simply offer a snapshot of what is happening on the plantation frontier. Further research in another time and space would 
yield comparable data and ethnographic accounts to enable us to understand the specificity of the human-centred epoch of which we are all a part.

\section{References}

Bonneuil, Christophe, and Jean-Baptiste Fressoz. 2017. The shock of the Anthropocene: The Earth, history and us. London: Verso.

Haddad, Nick M., Lars A. Brudvig, Jean Clobert, Kendi F. Davies, Andrew Gonzalez, Robert D. Holt, Thomas E. Lovejoy, Joseph O. Sexton, Mike P. Austin, Cathy D. Collins, William M. Cook, Ellen I. Damschen, Robert M. Ewers, Bryan L. Foster, Clinton N. Jenkins, Andrew J. King, William F. Laurance, Douglas J. Levey, Chris R. Margules, Brett A. Melbourne, A.O. Nicholls, John L. Orrock, Dan-Xia Song, and John R. Townshend. 2015. Habitat fragmentation and its lasting impact on Earth's ecosystems. Science Advances 1 (2): 1-9.

Haraway, Donna. 2015. Anthropocene, Capitalocene, Plantationocene, Chthulucene: Making kin. Environmental Humanities 6 (1): 159-165.

Haraway, Donna, Noboru Ishikawa, Scott F. Gilbert, Kenneth Olwig, Anna L. Tsing, and Nils Bubant. 2016. Anthropologists are talking_About the Anthropocene. Ethnos 81 (3): 535-564.

Kitayama, Kanehiro, ed. 2013. Co-benefits of sustainable forestry: Ecological studies of a certified Bornean rain forest. Tokyo: Springer.

Laurance, William F., Jose L.C. Camargo, Philip M. Fearnside, Thomas E. Lovejoy, G. Bruce Williamson, Rita C.G. Mesquita, Christoph F.J. Meyer, Paulo E.D. Bobrowiec, and Susan G.W. Laurance. 2016. An Amazonian forest and its fragments as a laboratory of global change. In Interactions between biosphere, atmosphere and human land use in the Amazon basin, ed. Laszlo Nagy, Bruce R. Forsberg, and Paulo Artaxo, 407-440. Berlin: Springer.

Lewis, Simon L., and Mark A. Maslin. 2015. Defining the Anthropocene. Nature 519: 171-180. . 2018. The human planet: How we created the Anthropocene. London: Penguin.

Mintz, Sidney W. 1959. The plantation as a socio-cultural type. In Plantation systems of the New World, ed. Research Institute for the Study of Man and Pan American Union, 42-50. Washington, DC: Pan American Union.

. 1985. Sweetness and power: The place of sugar in modern history. New York: Penguin. 1996. Enduring substances, trying theories: The Caribbean region as Oikoumene. Journal of the Royal Anthropological Institute 2 (2): 289-311.

Moor, James. 2017. The Capitalocene, Part I: On the nature and origins of our ecological crisis. Journal of Peasant Studies 44 (3): 594-630.

Steward, Julian H. [and others]. 1956. The people of Puerto Rico: A study in social anthropology. Urbana: University of Illinois Press.

Tsing, Anna Lowenhaupt. 2015a. The mushroom at the end of the world: On the possibility of life in capitalist ruins. Princeton: Princeton University Press.

. 2015b. Feral geographies: Life in capitalist ruins. Paper at RGS-IBG annual international conference, University of Exeter, 2 September.

- 2016. Others without history: Organisms as agility-shifting actors in the trajectory of capital. 11th Eric Wolf Lecture, Vienna, 17 October.

Turner, I.M. 1996. Species loss in fragments of tropical rain forest: A review of the evidence. Journal of Applied Ecology 33 (2): 200-209.

Wolf, Eric. 1982. Europe and the people without history. Berkeley: University of California Press.

Wulf, Andrea. 2015. The invention of nature: Alexander von Humboldt's New World. New York: Penguin. 
Open Access This chapter is licensed under the terms of the Creative Commons AttributionNonCommercial-NoDerivatives 4.0 International License (http://creativecommons.org/licenses/ by-nc-nd/4.0/), which permits any noncommercial use, sharing, distribution and reproduction in any medium or format, as long as you give appropriate credit to the original author(s) and the source, provide a link to the Creative Commons licence and indicate if you modified the licensed material. You do not have permission under this licence to share adapted material derived from this chapter or parts of it.

The images or other third party material in this chapter are included in the chapter's Creative Commons licence, unless indicated otherwise in a credit line to the material. If material is not included in the chapter's Creative Commons licence and your intended use is not permitted by statutory regulation or exceeds the permitted use, you will need to obtain permission directly from the copyright holder. 